Review

\title{
Secondary thyroid malignancy - a rare clinical finding?
}

\author{
Marius-Lucian Mitrache ${ }^{1, *}$, Gheorghiță Patriciu Zubașcu' ${ }^{1}$, Teodor Dumitraș ${ }^{1}$, Carmen \\ Sorina Martin ${ }^{1,2}$, Simona Fica ${ }^{1,2}$ \\ 'Department of Endocrinology, Elias University Emergency Hospital, Bucharest, Romania; ${ }^{2 " C a r o l}$ \\ Davila" University of Medicine and Pharmacy, Bucharest, Romania
}

\begin{abstract}
Metastases to the thyroid gland, while rarely seen in clinical practice, can pose a diagnostic and therapeutic challenge. Most commonly, they originate from lung, renal, and breast cancer, and are generally a sign of multiorgan metastatic disease. In most cases, metastases to the thyroid gland are diagnosed incidentally on imaging studies, since they are rarely symptomatic and often do not influence thyroid function tests. Thyroid ultrasonography and fine-needle aspiration biopsy play a pivotal role in their evaluation, as both classic immunocytochemical features, and more novel molecular markers can help in the differential diagnosis. Prognosis mainly depends on the biology of the primary tumor and its extension. Communication between clinicians is essential in such patients, in order to ensure that the treatment options are carefully balanced, thus raising the need for multidisciplinary teams in their management.
\end{abstract}

Keywords: metastasis to the thyroid; secondary malignancy

\section{Introduction}

Metastases to the thyroid gland are rarely seen in clinical practice and are usually associated with a high tumor burden and extensive metastatic disease [1-4]. Despite this, autopsy reports have suggested a much higher incidence, with secondary thyroid malignancy being identified in as many as $24 \%$ of patients with widespread metastatic disease $[5,6]$.

While clinical series report renal, breast, lung, and gastrointestinal cancers as the most frequent primary sites, autopsy series have reported the lung as the most common primary site, probably owing to the more aggressive nature of the latter [7-13].

Received: September 2021; Accepted after review: December 2021; Published: December 2021.

${ }^{*}$ Corresponding author: Marius-Lucian Mitrache, Department of Endocrinology, Elias University Emergency Hospital, Bucharest, Romania.

Email: lucian.mitrache@gmail.com
Considering the rich blood supply of the thyroid gland, the low incidence of thyroid metastasis is quite surprising. Willis suggested that this is due to the fast blood flow through the thyroid gland, as well as to the high iodine and oxygen content of the thyroid glandular tissue, which hinder tumor growth [14].

In recent years, however, the number of reported secondary thyroid malignancies has increased, since high resolution imaging, such as computed tomography (CT), magnetic resonance imaging (MRI), and 18Fluorodeoxyglucose positron emission tomography (18-FDG/PET) became standard practice for staging cancer patients, and diagnostic techniques such as thyroid fineneedle aspiration biopsy (FNAB) became readily available nowadays.

\section{Clinical characteristics}

A recent meta-analysis reported secondary thyroid malignancy to be more 
common in women than in men, usually occurring between 50 and 60 years of age [15].

It may be discovered simultaneously, or after the treatment of the primary malignancy, and in some cases, thyroid metastases are diagnosed more than 15 years after the diagnosis of the primary tumor, especially in neoplasia exhibiting a slower growth rate, such as renal cell carcinoma $[12,16]$. Thyroid metastases are usually found incidentally on imaging studies and are often asymptomatic. Rarely, when they are clinically evident, they present as a palpable neck mass which may associate dysphonia and dysphagia, and may mimic aggressive primary thyroid cancer, such as anaplastic carcinoma [17, 18]. Regarding thyroid function, most patients are euthyroid, with some cases reporting transient hyperthyroidism, most probably due to the infiltration and destruction of the normal thyroid tissue, and leakage of hormones [1922].

\section{Imaging}

Different imaging techniques can be used for detecting thyroid metastases. Neck ultrasonography is generally the first line employed, usually showing two patterns of thyroid invasion - either the nodular type, which presents as hypoechoic lesions with poorly-defined margins, irregular shapes, and high blood flow as shown by the color flow Doppler function, or the diffuse infiltrative type, in which a thyroid lobe or the whole gland is hypoechoic, with internal lines that alter its structure [23-25].

CT characteristics of secondary thyroid malignancy include hypodense lesions with inhomogeneous contrast enhancement when compared to the normal tissue [26].

On MRI, most thyroid metastases are isoto hyperintense in T1-weighted images, while in T2-weighted images they are slightly hyperintense in comparison to the normal thyroid. They often show central necrosis and inhomogeneous light contrast enhancement after the contrast medium is administered [26, 27].
In some cases, thyroid metastases are incidentally identified on 18-FDG/PET, and the probability of an FDG-positive focal thyroid lesion to be malignant can be as high as $63 \%$ as reported by some authors [28]. All thyroid malignancies, including metastases, show higher uptake in 18-FDG/PET compared to the normal tissue. However, diffuse or focal uptake may sometimes be seen in autoimmune thyroiditis, diffuse goiter, or adenomatous nodules. Thus, such areas justify further investigation in order to exclude malignancy. [29, 30].

\section{Pathology and the role of FNAB}

Over the past few decades, FNAB has become one of the most important tools in the assessment of thyroid nodules, including metastases, but it is not, however, infallible [31]. One study showed that FNAB yielded the correct diagnosis of metastasis to the thyroid in $73 \%$ of cases, citing multinodular goitre as a potential factor that can influence the accuracy of the diagnosis [32].

Cytological aspects include a mix of thyroid follicular cells and malignant cells, which may be typical of the primary tumor. The presence of atypia is unlikely in primary thyroid carcinomas, since they are usually low grade, and its presence is highly suggestive of metastasis [32]. While some types of metastatic cancers, particularly lung carcinoma, can simulate the growth pattern of thyroid cancer, immunocytochemical markers can further aid establish the diagnosis. Thus, metastases to the thyroid do not stain with anti-thyroglobulin and anti-calcitonin antibodies [32]. Other markers used for the differential diagnosis include renal clear cell carcinoma antigen (RCC Ag), GATA-3 and mammoglobin for metastatic breast cancer, melanoma antigen recognized by $T$ cells -1 (MART-1) for metastatic melanoma, and transcription termination factor-1 (TTF-1) for lung adenocarcinoma [33-36].

In a few selected cases, molecular markers such as p53 and BRAFV600E mutations have also been used to identify the primary tumor site and potentially select cases for targeted therapy [37]. 


\section{Treatment and prognosis}

While the survival of these patients is closely linked to the characteristics of the primary malignancy and its stage, the prognosis of secondary thyroid malignancy remains controversial.

Lung and esophageal cancers have the poorest prognosis, with a mean survival of 2 months after the diagnosis of the thyroid metastasis, whereas breast cancer, melanoma, and colorectal cancer have a better prognosis [2, 38, 39]. The longest overall survival is seen in patients with renal cell carcinoma, and it can be as high as 36 months after the detection of the thyroid metastases [38, 40].

Although secondary thyroid malignancy is generally considered a sign of widespread metastatic disease, several studies have pointed out that it should not be considered a surgical contraindication by itself $[15,38]$. Total thyroidectomy or lobectomy improved the one-year survival rates of renal cell carcinoma patients $(55 \%$ vs $35 \%$ in nonoperated patients) and the overall survival of patients, regardless of the primary tumor (36 vs 12 months). [38, 40]. In a selected group of patients in which the thyroid is the only metastatic site, surgery is considered the gold standard, and it can induce complete remission, with results showing survival rates up to 20 years, particularly in renal cell carcinoma [41]. Thyroidectomy can also be used palliatively in patients with thyroid metastases that cause compressive symptoms $[1,42]$.

As mentioned earlier, thyroid metastatic deposits can follow two patterns - diffuse, which usually involves either an entire lobe or the whole gland, and nodular, respectively. Compared to the nodular type, diffuse thyroid involvement has a poorer overall prognosis and is generally associated with extensive metastatic disease [25]. Interestingly, diffuse infiltration of the gland can cause its destruction, with the release of thyroid hormones into the circulation, rarely causing thyrotoxicosis, which can further impact the patient's outcome [43-45].
In patients with multiple metastases, systemic therapy, such as chemotherapy, should be considered, as it can improve survival rates, whereas the benefits of radiotherapy are controversial [46]. Molecular markers, such as epithelial growth factor receptor (EGFR) gene mutation, can also help in selecting candidates for targeted therapy. [47].

\section{Conclusions}

Metastatic disease to the thyroid gland, while infrequent, should be suspected in patients with thyroid lesions and history of malignant disease, particularly of renal, lung, and breast cancer, as they have been shown to be the most frequent primary sites in both clinical and autopsy reports. As they are rarely clinically noticeable, thyroid metastases are usually identified by imaging studies, and red flags such as rich intranodular vascularization in ultrasound or high uptake in 18-FDG/PET warrant the further investigation of a thyroid lesion. FNAB can further aid the clinician, as there are both cytological characteristics that can suggest the diagnosis, and immunocytochemical and molecular markers that can identify the primary tumour. Prognosis largely depends on the biological features of the primary tumor and the disease stage, with patient survival ranging from as short as 2 months in lung cancer, up to 20 years in renal carcinoma. In the rare setting where the thyroid is the only secondary site, thyroidectomy can virtually induce complete remission. However, thyroid involvement is usually the hallmark of widespread metastatic disease. Thus, such cases should be managed in a multidisciplinary team, allowing for a tailored approach and individualized therapy.

\section{Conflict of Interest}

The authors declare that they have no conflict competing of interest.

\section{Consent for publication}

Written informed consent from the patient has been taken and is available for review by Editor in chief of the journal. 


\section{References}

1. Lam KY, Lo CY. Metastatic tumors of the thyroid gland: a study of 79 cases in Chinese patients. Arch Pathol Lab Med. 1998; 122(1):37-41.

2. Papi G, Fadda G, Corsello SM, et al. Metastases to the thyroid gland: prevalence, clinicopathological aspects and prognosis: a 10-year experience. Clin Endocrinol (Oxf). 2007; 66(4):565-571. https://doi.org/10.1111/j.13652265.2007.02773.x

3. Cordes $M$, Kuwert $T$. Metastases of nonthyroidal tumors to the thyroid gland: a regional survey in Middle Franconia. Exp Clin Endocrinol Diabetes. 2014; 122(5):273-276. https://doi.org/10.1055/s-0034-1372623

4. Moghaddam PA, Cornejo KM, Khan A. Metastatic carcinoma to the thyroid gland: a single institution 20-year experience and review of the literature. Endocr Pathol. 2013; 24(3):116-24. https://doi.org/10.1007/s12022$\underline{013-9257-8}$

5. Silverberg SG, Vidone RA. Metastatic tumors in the thyroid. Pacific Med Surg. 1966; 74:175180.

6. Mistelou A, Papadatos SS, Kousi Ch, et al. Thyroid gland as a target of secondary malignancies; an autopsy study and review data. Folia Med (Plovdiv). 2019; 61(2):277-288.

7. Heffess CS, Wenig BM, Thompson LD. Metastatic renal cell carcinoma to the thyroid gland: a clinicopathologic study of 36 cases. Cancer. 2002; 95(9):1869-1878. https://doi.org/10.1002/cncr.10901

8. Calkovsky V, Szepe P, Hajtman A. Solitary intrathyroid metastasis of renal cancer. Bratisl Lek Listy. 2011; 112(7):395-397.

9. Plonczak AM, DiMarco AN, Dina R, Gujral DM, Palazzo FF. Breast cancer metastases to the thyroid gland - an uncommon sentinel for diffuse metastatic disease: a case report and review of the literature. J Med Case Rep. 2017; 11(1):269. https://doi.org/10.1186/s13256-0171441-x

10. Rosen IB, Walfish PG, Bain J, Bedard YC. Secondary malignancy of the thyroid gland and its management. Ann Surg Oncol. 1995; 2(3):252-256.

https://doi.org/10.1007/BF02307032

11. Nixon IJ, Coca-Pelaz A, Kaleva Al, et al. Metastasis to the thyroid gland: a critical review. Ann Surg Oncol. 2017; 24(6):15331539 https://doi.org/10.1245/s10434-016-56834

12. Hegerova L, Griebeler ML, Reynolds JP, Henry MR, Gharib H. Metastasis to the thyroid gland: report of a large series from the Mayo Clinic. Am J Clin Oncol. 2015; 38(4):338-342. doi:10.1097/COC.0b013e31829d1d09

13. Mitselou A, Vougiouklakis T, Peschos D, Dallas $P$, Agnantis NJ. Occult thyroid carcinoma. A study of 160 autopsy cases. The first report for the region of Epirus-Greece. Anticancer Res. 2002; 22(1A):427-432.

14. Willis RA. Metastatic tumours in the thyroid gland. Am J Pathol. 1931; 7(3):187-208.

15. Straccia $P$, Mosseri $C$, Brunelli $C$, et al. Diagnosis and treatment of metastases to the thyroid gland: a meta-analysis. Endocr Pathol. 2017; 28(2):112-120. https://doi.org/10.1007/s12022-017-9475-6

16. Nakhjavani MK, Gharib $H$, Goellner JR, van Heerden JA. Metastasis to the thyroid gland. A report of 43 cases. Cancer. 1997; 79(3):574$578 . \quad$ https://doi.org/10.1002/(sici)10970142(19970201)79:3<574::aidcncr21>3.0.co;2-\#

17. Elliott RH Jr, Frantz VK. Metastatic carcinoma masquerading as primary thyroid cancer: a report of authors' 14 cases. Ann Surg. 1960; 151(4):551-561. https://doi.org/10.1097/00000658-19600400000015

18. Chen H, Nicol TL, Udelsman R. Clinically significant, isolated metastatic disease to the thyroid gland. World J Surg. 1999; 23(2):177180; discussion 181. https://doi.org/10.1007/pl00013162

19. Tibaldi JM, Shapiro LE, Mahadevia PS. Thyroiditis mimicked by metastatic carcinoma to the thyroid. Mayo Clin Proc. 1986; 61(5):399-400. https://doi.org/10.1016/s00256196(12)61962-4

20. Miyakawa $M$, Sato $K$, Hasegawa $M$, et al. Severe thyrotoxicosis induced by thyroid metastasis of lung adenocarcinoma: a case report and review of the literature. Thyroid. 2001; 11(9):883-888. https://doi.org/10.1089/105072501316973154

21. Wirtz G, Quoix E, Grunenberger F, Massard G, Mennecier B. Thyroid metastasis of lung cancer and abnormal thyroid function-a case report. Rev Pneumol Clin. 2009; 65(1):27-31. https://doi.org/10.1016/i.pneumo.2008.08.003

22. Jonklaas J. Infiltration of the thyroid gland by non-thyroid malignancy: A literature review reveals this to be an unusual cause of hyperthyroidism. J Clin Transl Endocrinol. 2020; 20:100221. https://doi.org/10.1016/j.jcte.2020.100221

23. Falcone $R$, Ramundo $V$, Lamartina $L$, et al. Sonographic presentation of metastases to the 
thyroid gland: a case series. $J$ Endocr Soc. 2018; 2(8):855-859. https://doi.org/10.1210/js.2018-00124

24. Saito $\mathrm{Y}$, Sugitani I, Toda K, Yamada K, Fujimoto $Y$. Metastatic thyroid tumors: ultrasonographic features, prognostic factors and outcomes in 29 cases. Surg Today. 2014; 44(1):55-61. https://doi.org/10.1007/s00595013-0492-x

25. Kim HK, Kim SS, Oak CY, Kim SJ, Yoon JH, Kang HC. Diffuse metastasis to the thyroid: unique ultrasonographic finding and clinical correlation. J Korean Med Sci. 2014; 29(6):818824.

https://doi.org/10.3346/jkms.2014.29.6.818

26. Surov A, Machens A, Holzhausen $\mathrm{HJ}$, Spielmann RP, Dralle H. Radiological features of metastases to the thyroid. Acta Radiol. 2016; 57(4):444-450.

https://doi.org/10.1177/0284185115581636

27. Takashima S, Takayama F, Wang JC, et al. Radiologic assessment of metastases to the thyroid gland. J Comput Assist Tomogr. 2000; 24(4):539-545.

https://doi.org/10.1097/00004728-200007000$\underline{00005}$

28. Chen $W$, Parsons $M$, Torigian DA, Zhuang $H$, Alavi A. Evaluation of thyroid FDG uptake incidentally identified on FDG-PET/CT imaging. Nucl Med Commun. 2009; 30(3):240-244. https://doi.org/10.1097/00004728-200007000$\underline{00005}$

29. Purohit BS, Ailianou A, Dulguerov N, Becker CD, Ratib O, Becker M. FDG-PET/CT pitfalls in oncological head and neck imaging. Insights Imaging. 2014; 5(5):585-602. https://doi.org/10.1007/s13244-014-0349-x

30. Rahman WT, Wale DJ, Viglianti BL, et al. The impact of infection and inflammation in oncologic 18F-FDG PET/CT imaging. Biomed Pharmacother. 2019; 117:109168. https://doi.org/10.1016/j.biopha.2019.109168

31. Agcaoglu O, Aksakal N, Ozcinar B, et al. Factors that affect the false-negative outcomes of fine-needle aspiration biopsy in thyroid nodules. Int J Endocrinol. 2013; 2013:126084. https://doi.org/10.1155/2013/126084

32. Chung AY, Tran TB, Brumund KT, Weisman RA, Bouvet M. Metastases to the thyroid: a review of the literature from the last decade. Thyroid. 2012; 22(3):258-268. https://doi.org/10.1089/thy.2010.0154

33. Tan $\mathrm{PH}$, Cheng $\mathrm{L}$, Rioux-Leclercq $\mathrm{N}$, et al. Renal tumors: diagnostic and prognostic biomarkers. Am J Surg Pathol. 2013; 37(10):1518-1531. https://doi.org/10.1097/PAS.0b013e318299f12 $\underline{\mathrm{e}}$
34. Miettinen M, McCue PA, Sarlomo-Rikala M, et al. GATA 3 : a multispecific but potentially useful marker in surgical pathology-a systematic analysis of 2500 epithelial and nonepithelial tumors. Am J Surg Pathol. 2014; 38(1):13-22. https://doi.org/10.1097/PAS.0b013e3182a0218 f

35. Gucer $\mathrm{H}$, Mete $\mathrm{O}$. Positivity for $\mathrm{GATA}_{3}$ and TTF-1 (SPT 24$)$, and negativity for monoclonal PAX8 expand the biomarker profile of the solid cell nests of the thyroid gland. Endocr Pathol. 2018; 29(1):49-58. https://doi.org/10.1007/s12022-017-9511-6

36. Ordonez NG. Value of melanocytic-associated immunohistochemical markers in the diagnosis of malignant melanoma: a review and update. Hum Pathol. 2014; 45(2):191-205. https://doi.org/10.1016/j.humpath.2013.02.007

37. Xing M, Tufano RP, Tufaro AP, et al. Detection of BRAF mutation on fine needle aspiration biopsy specimens: a new diagnostic tool for papillary thyroid cancer. J Clin Endocrinol Metab. 2004; 89(6):2867-2872. https://doi.org/10.1210/jc.2003-032050

38. Romero Arenas MA, Ryu H, Lee $\mathrm{S}$, et al. The role of thyroidectomy in metastatic disease to the thyroid gland. Ann Surg Oncol. 2014; 21(2):434-439. https://doi.org/10.1245/s10434013-3282-1

39. Zhang L, Liu Y, Li X, Gao W, Zheng $\mathrm{C}$. Metastases to the thyroid gland: A report of 32 cases in PUMCH. Medicine (Baltimore). 2017; 96(36):e7927.

https://doi.org/10.1097/MD.0000000000007927

40. Khaddour K, Marernych N, Ward WL, Liu J, Pappa T. Characteristics of clear cell renal cell carcinoma metastases to the thyroid gland: A systematic review. World J Clin Cases. 2019; $7(21): 3474-3485$.

https://doi.org/10.12998/wjcc.v7.i21.3474

41. Papi G, Corrado S, Scaltriti L, Carapezzi C, Ezzat S. Metastasis of urothelial sarcomatoid carcinoma to a toxic multinodular goiter. Endocr Pathol. 2005; 16(2):153-156. https://doi.org/10.1385/ep:16:2:153

42. Calzolari F, Sartori PV, Talarico C, et al. Surgical treatment of intrathyroid metastases: Preliminary results of a multicentric study. Anticancer Res. 2008; 28(5B):2885-2888.

43. Kung AW, Lorentz $T$, Tsui $E$, Wang $C$. Carcinomatous infiltration of the thyroid presenting as thyroiditis and stridor. Horm Metab Res. 1991; 23(10):509-510. https://doi.org/10.1055/s-2007-1003741

44. Shirahama T, Ashitani J, Kodama T, et al. A case of lung cancer with hyperthyroidism. Nihon Kokyuki Gakkai Zasshi. 2008; 46(4):308-313. 
45. Rosen IB, Strawbridge HG, Walfish PG, Bain J. Malignant pseudothyroiditis: a new clinical entity. Am J Surg. 1978; 136(4):445-449. https://doi.org/10.1016/0002-9610(78)90258-1

46. Kim TY, Kim WB, Gong G, Hong SJ, Shong YK. Metastasis to the thyroid diagnosed by fine-needle aspiration biopsy. Clin Endocrinol (Oxf). 2005; 62(2):236-241. https://doi.org/10.1111/j.13652265.2005.02206.x
47. Bellevicine C, Vigliar E, Malapelle U, et al. Lung adenocarcinoma and its thyroid metastasis characterized on fine-needle aspirates by cytomorphology, immunocytochemistry, and nextgeneration sequencing. Diagn Cytopathol. 2015; 43(7):585-589.

https://doi.org/10.1002/dc.23264 